\title{
DRIS standard and normal ranges of foliar nutrients for the culture of 'Thompson' atemoya
}

\section{Eduardo Maciel Haitzmann dos Santos ${ }^{1}$ Danilo Eduardo Rozane ${ }^{2}$}

\author{
'Programa de Pós-graduação em Ciência do Solo (PPGCS), Departamento de Solos e Engenharia Agrícola, Universidade Federal do Paraná \\ (UFPR), Curitiba, PR, Brasil. \\ ${ }^{2}$ Universidade Estadual Paulista "Júlio de Mesquita Filho" (UNESP), 11900-000, Campus de Registro, Registro, SP, Brasil. E-mail: \\ danilorozane@registro.unesp.br. Corresponding author.
}

\begin{abstract}
Atemoya, an interspecific hybrid belonging to Annonaceae family, is the outcome of a cross between cherimoya (Annona cherimola Mill.) and Custard apple (Annona squamosa L.). In light of the current shortage of scientific data on the nutritional management techniques for this fruit, the need to develop and apply a specific methodology becomes crucial. From the variety of plant diagnostic tools available, the DRIS method was selected, for use in the commercial cultivation of the 'Thompson' cultivar of atemoya located in the São Paulo State, municipalities of Itapetininga, Piedade, Pilar do Sul and Salto de Pirapora. Normal nutrient ranges were determined to interpret the levels of $N, P, K, C a, M g, S, B, C u, F e, M n$ and Zn in the culture through statistical regression analysis and samples of leaf dry matter, with their respective DRIS indices. Although the general index of the nutritional balance of DRIS disallowed establishing a link with productivity, this study achieved it based on the standard of determining normal ranges for cognate macronutrients to the ones cited in the literature.
\end{abstract}

Key words: Annonaceae, Mineral nutrition, foliar diagnosis, nutritional balance.

Norma DRIS e faixas normais de nutrientes foliares para a cultura da atemoia 'Thompson'

RESUMO: A atemoia é um híbrido interespecifico, da família da Annonaceae, obtido pelo cruzamento da cherimoia (Annona cherimola Mill.) e a fruta-pinha (Annona squamosa L.). Devido a falta de informações cientificas disponiveis para a fruta sobre os procedimentos de manejo nutricional, o desenvolvimento e a aplicação de uma metodologia especifica são de grande importância. Dentre as ferramentas disponiveis para a realização da diagnose de plantas temos o método DRIS. Este foi empregado em talhões comerciais de atemoia do cultivar 'Thompson' nos municípios do estado de São Paulo: Itapetininga, Piedade, Pilar do Sul e Salto de Pirapora. A determinação das faixas normais de nutrientes para a interpretação dos níveis de $\mathrm{N}, \mathrm{P}, \mathrm{K}, \mathrm{Ca}, \mathrm{Mg}, \mathrm{S}, \mathrm{B}, \mathrm{Cu}, \mathrm{Fe}, \mathrm{Mn}$ e Zn na cultura foram obtidas pela análise estatística de regressão relacionando os seus teores, presentes nas matérias secas das amostras foliares com seus respectivos índices DRIS. Embora o indice geral de balanço nutricional do DRIS não tenha permitido estabelecer uma relação com a produtividade, foi possível, com base na norma, determinar faixas normais para macronutrientes semelhantes aos encontrados na literatura.

Palavras-chave: Annonaceae, nutrição mineral, diagnose foliar, balanço nutricional.

\section{INTRODUCTION}

Among the several genres of the Annonaceae family many have great commercial value, Annona being the most prominent. Cherimoya, Custard apple and the atemoya cultures belong to this genus. Atemoya, an interspecific hybrid, is the result of a genetic cross between cherimoya (Annona cherimola Mill.) with Custard apple (Annona squamosa L.) (SILVA \& MUNIZ, 2011), emphasizing the cultivation of the cultivars like 'African Pride', 'Bradley', 'Gefner' and 'Thompson' in the tropical belt.
São Paulo is the principal producing state in Brazil where the small producers perform the majority of the cultivation. With the escalating demand for the annonaceous fruit pulp in Brazil, there is a great need to supply both the national and international markets. The paucity of specific technical data currently available for the crop and the correct methods of liming, fertilization and nutrition besides the diagnostic tools for producer orientation, emphasize the pressing necessity for targeted research (ROZANE \& NATALE, 2014).

Among the tools available to estimate the nutritional status of plants which can be applied 
for atemoya, the Diagnosis and Recommendation Integrated System (DRIS), recommended by BEAUFILS (1973) appears suitable. In light of the bivariate relationships (existing between two nutrients), this method enables the categorization of the nutrients and identifies the elements that are present in limitation by excess and lack; it is thus still feasible to assess the indices that reveal the relative balance of the nutrients.

This study aimed to establish the DRIS standard and range of nutrient sufficiency available in the plant dry matter, particularly in the leaf samples of atemoieiras of the 'Thompson' cultivar.

\section{MATERIALS AND METHODS}

To correctly assess the nutritional status of the atemoya crop, three harvests in the agricultural years of 2013/2014, 2014/2015 and 2015/2016 were performed, to collect data from 50 commercial, adult and irrigated fields located in the principal producing region of Brazil, from the Itapetininga, Piedade, Pilar do Sul and Salto de Pirapora municipalities. The climate prevailing there is typically subtropical, with dry winters and hot summers (Cwa) according to the classification of Köppen-Geiger.

The areas sampled were cultivating the 'Thompson' crown and 'Araticum-de-TerraFria' rootstock (Rollinia sp.), with an average $6 \mathrm{~m}$ line spacing and $4.5 \mathrm{~m}$ interline. To determine the nutritional status, each commercial stand contributed a composite sample, each represented by a collection of 25 simple subsamples.

When full flowering of the crop was achieved leaf sampling was done based on the method of ROZANE \& NATALE (2014). Fully mature leaves (third pair of leaves) were gathered from the four cardinal points and at the median height of the trees from the flower-bearing branches. Sheets were subjected to washing in a specified sequence as follows: running water; deionized water solution with neutral detergent $(0.1 \%)$; deionized water solution with hydrochloric acid $(0.3 \%)$; deionized water. Drying was followed, using the forced air ventilation oven at $60 \pm 5^{\circ} \mathrm{C}$ until constant mass was achieved. It was then ground in a Willey mill, with a $0.841 \mathrm{~mm}$ (20 mesh) sieve, for future nutrient determination, according to the procedure of BATAGLIA et al. (1983). The $\mathrm{N}$ was assessed by micro-Kjeldahl including nitrate; $\mathrm{P}$ and $\mathrm{S}$ were estimated by colorimetry; the cations $(\mathrm{K}, \mathrm{Ca}$, $\mathrm{Mg}, \mathrm{Cu}, \mathrm{Fe}, \mathrm{Mn}$ and $\mathrm{Zn}$ ) were by quantified by atomic absorption spectrophotometry after being treated with a nitric acid and perchloric acid mixture; boron was determined by colorimetry post calcination residue for $3 \mathrm{~h}$ in a muffle furnace set to $550^{\circ} \mathrm{C}$.

Each plot was assessed for productivity by multiplying the average of the total number of fruits counted on 10 plants, roughly 30 days prior to harvest onset, with the average weight of 100 fruits during the full harvest. According to the levels of the macronutrients $\left(\mathrm{g} \mathrm{kg}^{-1}\right)$ and micronutrients $\left(\mathrm{mg} \mathrm{kg}^{-1}\right)$ present in the foliar tissue, as well as the Atemoyas yield $\left(\mathrm{t} \mathrm{ha} \mathrm{h}^{-1}\right.$ ) estimated for the agricultural crops, the DRIS standard was established by implementing the bivariate relationships of the log-transformed models, as suggested by BEVERLY (1987).

To establish the norm, the database distinguished the groups into high productivity populations or reference populations, if their productivity exceeds the calculated average productivity, (normally between 19.0 and $48.1 \mathrm{t} \mathrm{ha}^{-1}$ ) and the low productivity populations, revealing productivity between 5.5 and $19.0 \mathrm{tha}^{-1}$. Once the populations were segregated, the Gaussian distribution of the high productivity population was observed using the Shapiro-Wilk test, including the probability of error.

Interpretation of the indices thus obtained by DRIS standard was done based on the potential response to fertilization (PRA), in its 5 response classes, viz., positive (p), positive or nil (pz), null $(\mathrm{z})$, negative or nil (nz) and negative (n), as proposed by WADT (2005). The classes thus demarcated were grouped and named, based on their influence on the productivity, as follows: limiting by lack $(\mathrm{LF}=\mathrm{p}+$ $\mathrm{pz})$, limiting by excess $(\mathrm{LE}=\mathrm{n}+\mathrm{nz})$, or non-limiting $(\mathrm{NL}=\mathrm{n})$, according to SILVA et al. (2005).

Utilizing the chi-square test $\left(\chi^{2}\right)$ at $5 \%$ probability, the frequencies with which the nutrients were present in the LF, LE and NL classes were analyzed to confirm the hypothesis that the frequencies observed (FO) are not statistically different from the frequencies expected (FE). Regarding the application of the $\chi^{2}$ test, less than $20 \%$ of the frequencies expected were to drop below 5 and none were to be equal to zero, according to the classes grouping method of GUIMARÃES (2008). For application of the chi-square test, the frequencies expected from as follows: limiting by lack $(\mathrm{LF}=\mathrm{p}+$ $\mathrm{pz})$, limiting by excess ( $\mathrm{LE}=\mathrm{n}+\mathrm{nz}$ ), or non-limiting $(\mathrm{NL}=\mathrm{n})$, according to SILVA et al. (2005).

Appropriate levels of each nutrient were determined, and similar to the method adopted by SOUZA et al. (2015). Their relationships with their respective nutritional balance index were thus drawn. Using the regression analysis method the foliar content of each nutrient was assessed, and equations were obtained relating the nutrient contents with their respective DRIS 
indexes. Lower (LI) and upper (LS) limits of the normal range were ascertained by equalizing the statistical models to zero, subtracting and adding the value found in the ratio of $2 / 3$ of the value of the standard deviation of contents of each nutrient, respectively.

\section{RESULTS AND DISCUSSION}

Among the population assessed, 23 fields $(46 \%)$ were categorized as high productivity class (nutritional reference), while 27 fields (54\%) were assigned to the low productivity class. Populations revealed normality in the data through the ShapiroWilk test $(\mathrm{W}=0.91468 ; \mathrm{P}=0.0152)$. Dual relations were transformed to the required logarithmic scale of the DRIS standard of BEVERLY (1987) to eliminate the degree of flattening the distribution of values in relation to the normal curve (kurtosis effect) in the coefficient of variation. Table 1 lists the averages of the bivariate relations and their respective standard deviations, used to establish the norm.

The method adopted from URANO et al. (2006), provided the parameters with which the differences in the probability of the positive responses to fertilization could be diagnosed, i.e., the frequency at which the nutrients assessed were limited by lack or excess in the atemoya culture (Table 2).

Data distribution facilitated the rejection of the hypothesis that the frequencies noted for the nutrients were statistically similar to the frequencies expected in

Table 1 - Mean $(\bar{x})$ and standard deviations $(\sigma)$ of the relationships between the concentrations of two nutrients in the leaf dry matter samples taken from the high productivity population of 'Thompson' atemoyas to establish the DRIS standard.

\begin{tabular}{|c|c|c|c|c|c|c|c|c|c|c|}
\hline $\mathrm{N} /$ & $\mathrm{P}$ & $\mathrm{K}$ & $\mathrm{Ca}$ & $\mathrm{Mg}$ & $\mathrm{S}$ & B & $\mathrm{Cu}$ & $\mathrm{Fe}$ & $\mathrm{Mn}$ & $\mathrm{Zn}$ \\
\hline $\bar{x}$ & $1.37^{*}$ & $0.29^{*}$ & $0.34^{*}$ & $1.01^{*}$ & $1.23^{*}$ & $-0.30^{*}$ & $0.50^{*}$ & $-0.47^{*}$ & $-0.43^{*}$ & $-0.01^{*}$ \\
\hline$\sigma$ & 0.29 & 0.07 & 0.12 & 0.13 & 0.14 & 0.10 & 0.18 & 0.16 & 0.29 & 0.37 \\
\hline $\mathrm{P} /$ & $\mathrm{N}$ & $\mathrm{K}$ & $\mathrm{Ca}$ & $\mathrm{Mg}$ & S & B & $\mathrm{Cu}$ & $\mathrm{Fe}$ & $\mathrm{Mn}$ & $\mathrm{Zn}$ \\
\hline $\bar{x}$ & $-1.37^{*}$ & $-1.08^{*}$ & $-1.03^{*}$ & $-0.36^{*}$ & $-0.14^{*}$ & $-1.67^{*}$ & $-0.87^{*}$ & $-1.84^{*}$ & $-1.80^{*}$ & $-1.38^{*}$ \\
\hline$\sigma$ & 0.29 & 0.28 & 0.27 & 0.30 & 0.23 & 0.31 & 0.40 & 0.35 & 0.35 & 0.40 \\
\hline $\mathrm{K} /$ & $\mathrm{N}$ & $\mathrm{P}$ & $\mathrm{Ca}$ & $\mathrm{Mg}$ & S & B & $\mathrm{Cu}$ & $\mathrm{Fe}$ & $\mathrm{Mn}$ & $\mathrm{Zn}$ \\
\hline $\bar{x}$ & $-0.29^{*}$ & $1.08^{*}$ & $0.04^{*}$ & $0.71^{*}$ & $0.93^{*}$ & $-0.59^{*}$ & $0.21^{*}$ & $-0.76 *$ & $-0.72^{*}$ & $-0.31^{*}$ \\
\hline$\sigma$ & 0.07 & 0.28 & 0.12 & 0.16 & 0.13 & 0.08 & 0.18 & 0.14 & 0.29 & 0.32 \\
\hline $\mathrm{Ca} /$ & $\mathrm{N}$ & $\mathrm{P}$ & $\mathrm{K}$ & $\mathrm{Mg}$ & $\mathrm{S}$ & B & $\mathrm{Cu}$ & $\mathrm{Fe}$ & $\mathrm{Mn}$ & $\mathrm{Zn}$ \\
\hline $\bar{x}$ & $-0.34^{*}$ & $1.03^{*}$ & $-0.04^{*}$ & $0.67^{*}$ & $0.89^{*}$ & $-0.64^{*}$ & $0.16^{*}$ & $-0.80^{*}$ & $-0.76^{*}$ & $-0.35^{*}$ \\
\hline$\sigma$ & 0.12 & 0.27 & 0.12 & 0.10 & 0.16 & 0.15 & 0.21 & 0.22 & 0.32 & 0.39 \\
\hline $\mathrm{Mg} /$ & $\mathrm{N}$ & $\mathrm{P}$ & K & $\mathrm{Ca}$ & S & B & $\mathrm{Cu}$ & $\mathrm{Fe}$ & $\mathrm{Mn}$ & $\mathrm{Zn}$ \\
\hline $\bar{x}$ & $-1.01^{*}$ & $0.36^{*}$ & $-0.71^{*}$ & $-0.67^{*}$ & $0.22^{*}$ & $-1.31^{*}$ & $-0.50^{*}$ & $-1.47^{*}$ & $-1.43^{*}$ & $-1.02^{*}$ \\
\hline$\sigma$ & 0.13 & 0.30 & 0.16 & 0.10 & 0.19 & 0.18 & 0.18 & 0.23 & 0.34 & 0.43 \\
\hline $\mathrm{S} /$ & $\mathrm{N}$ & $\mathrm{P}$ & K & $\mathrm{Ca}$ & $\mathrm{Mg}$ & B & $\mathrm{Cu}$ & $\mathrm{Fe}$ & $\mathrm{Mn}$ & $\mathrm{Zn}$ \\
\hline $\bar{x}$ & $-1.23^{*}$ & $0.14^{*}$ & $-0.93^{*}$ & $-0.89^{*}$ & $-0.22^{*}$ & $-1.53^{*}$ & $-0.72^{*}$ & $-1.69^{*}$ & $-1.65^{*}$ & $-1.24^{*}$ \\
\hline$\sigma$ & 0.14 & 0.23 & 0.13 & 0.16 & 0.19 & 0.13 & 0.24 & 0.18 & 0.27 & 0.32 \\
\hline B / & $\mathrm{N}$ & $\mathrm{P}$ & K & $\mathrm{Ca}$ & $\mathrm{Mg}$ & S & $\mathrm{Cu}$ & $\mathrm{Fe}$ & $\mathrm{Mn}$ & $\mathrm{Zn}$ \\
\hline $\bar{x}$ & $0.30^{*}$ & $1.67^{*}$ & $0.59^{*}$ & $0.64^{*}$ & $1.31^{*}$ & $1.53^{*}$ & $0.80^{*}$ & $-0.17^{*}$ & $-0.13^{*}$ & $0.29^{*}$ \\
\hline$\sigma$ & 0.10 & 0.31 & 0.08 & 0.15 & 0.18 & 0.13 & 0.18 & 0.13 & 0.30 & 0.33 \\
\hline $\mathrm{Cu} /$ & $\mathrm{N}$ & $\mathrm{P}$ & K & $\mathrm{Ca}$ & $\mathrm{Mg}$ & $\mathrm{S}$ & B & $\mathrm{Fe}$ & $\mathrm{Mn}$ & $\mathrm{Zn}$ \\
\hline $\bar{x}$ & $-0.50^{*}$ & $0.87^{*}$ & $-0.21^{*}$ & $-0.16^{*}$ & $0.50^{*}$ & $0.72^{*}$ & $-0.80^{*}$ & $-0.97^{*}$ & $-0.93^{*}$ & $-0.51^{*}$ \\
\hline$\sigma$ & 0.18 & 0.40 & 0.18 & 0.21 & 0.18 & 0.24 & 0.18 & 0.20 & 0.37 & 0.41 \\
\hline $\mathrm{Fe} /$ & $\mathrm{N}$ & $\mathrm{P}$ & K & $\mathrm{Ca}$ & $\mathrm{Mg}$ & $\mathrm{S}$ & B & $\mathrm{Cu}$ & $\mathrm{Mn}$ & $\mathrm{Zn}$ \\
\hline $\bar{x}$ & $0.47^{*}$ & $1.84^{*}$ & $0.76^{*}$ & $0.80^{*}$ & $1.47^{*}$ & $1.69^{*}$ & $0.17^{*}$ & $0.97^{*}$ & $0.04^{*}$ & $0.45^{*}$ \\
\hline$\sigma$ & 0.16 & 0.35 & 0.14 & 0.22 & 0.23 & 0.18 & 0.13 & 0.20 & 0.31 & 0.33 \\
\hline $\mathrm{Mn} /$ & $\mathrm{N}$ & $\mathrm{P}$ & $\mathrm{K}$ & $\mathrm{Ca}$ & $\mathrm{Mg}$ & S & B & $\mathrm{Cu}$ & $\mathrm{Fe}$ & $\mathrm{Zn}$ \\
\hline $\bar{x}$ & $0.43^{*}$ & $1.80^{*}$ & $0.72^{*}$ & $0.76^{*}$ & $1.43^{*}$ & $1.65^{*}$ & $0.13^{*}$ & $0.93^{*}$ & $-0.04^{*}$ & $0.41^{*}$ \\
\hline$\sigma$ & 0.29 & 0.35 & 0.29 & 0.32 & 0.34 & 0.27 & 0.30 & 0.37 & 0.31 & 0.38 \\
\hline $\mathrm{Zn} /$ & $\mathrm{N}$ & $\mathrm{P}$ & K & $\mathrm{Ca}$ & $\mathrm{Mg}$ & $\mathrm{S}$ & B & $\mathrm{Cu}$ & $\mathrm{Fe}$ & $\mathrm{Mn}$ \\
\hline $\bar{x}$ & $0.01^{*}$ & $1.38^{*}$ & $0.31^{*}$ & $0.35^{*}$ & $1.02^{*}$ & $1.24^{*}$ & $-0.29^{*}$ & $0.51^{*}$ & $-0.45^{*}$ & $-0.41^{*}$ \\
\hline$\sigma$ & 0.37 & 0.40 & 0.32 & 0.39 & 0.43 & 0.32 & 0.33 & 0.41 & 0.33 & 0.38 \\
\hline
\end{tabular}

${ }^{*}$ Normal distribution by Kolmogorov-Smirnov test at 5\% $(\mathrm{P}>0.05)$. 
Table 2 - The observed frequency (\%) and grouping of the fertilization response potential observed for high and low productivity populations, based on the 'Thompson' leaf samples.

\begin{tabular}{|c|c|c|c|c|c|c|c|c|c|c|c|}
\hline PRA & $\mathrm{N}$ & $\mathrm{P}$ & $\mathrm{K}$ & $\mathrm{Ca}$ & $\mathrm{Mg}$ & $\mathrm{S}$ & $\mathrm{B}$ & $\mathrm{Cu}$ & $\mathrm{Fe}$ & Mn & $\mathrm{Zn}$ \\
\hline \multicolumn{12}{|c|}{-------------------------------------------------------------High productivity population---------------------------------------------------------------- } \\
\hline$P$ & 0.00 & 17.39 & 0.00 & 13.04 & 13.04 & 4.35 & 4.35 & 8.70 & 4.35 & 13.04 & 21.74 \\
\hline$p z$ & 21.74 & 4.35 & 4.35 & 4.35 & 4.35 & 13.04 & 4.35 & 17.39 & 21.74 & 17.39 & 17.39 \\
\hline$Z$ & 60.87 & 60.87 & 78.26 & 69.57 & 69.57 & 56.52 & 78.26 & 56.52 & 47.83 & 39.13 & 26.09 \\
\hline$n z$ & 13.04 & 8.70 & 13.04 & 8.70 & 4.35 & 26.09 & 8.70 & 8.70 & 13.04 & 13.04 & 8.70 \\
\hline$N$ & 4.35 & 8.70 & 4.35 & 4.35 & 8.70 & 0.00 & 4.35 & 8.70 & 13.04 & 17.39 & 26.09 \\
\hline $\mathrm{LF}$ & 21.74 & 21.74 & 4.35 & 17.39 & 17.39 & 17.39 & 8.70 & 26.09 & 26.09 & 30.43 & 39.13 \\
\hline NL & 60.87 & 60.87 & 78.26 & 69.57 & 69.57 & 56.52 & 78.26 & 56.52 & 47.83 & 39.13 & 26.09 \\
\hline LE & 17.39 & 17.39 & 17.39 & 13.04 & 13.04 & 26.09 & 13.04 & 17.39 & 26.09 & 30.43 & 34.78 \\
\hline \multicolumn{12}{|c|}{ 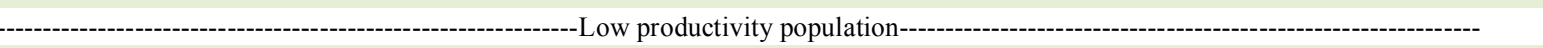 } \\
\hline$P$ & 3.70 & 11.11 & 0.00 & 11.11 & 7.41 & 3.70 & 3.70 & 18.52 & 14.81 & 22.22 & 3.70 \\
\hline$p z$ & 11.11 & 0.00 & 7.41 & 14.81 & 0.00 & 7.41 & 18.52 & 25.93 & 11.11 & 14.81 & 14.81 \\
\hline$Z$ & 74.07 & 40.74 & 55.56 & 55.56 & 77.78 & 66.67 & 70.37 & 37.04 & 59.26 & 22.22 & 70.37 \\
\hline$n z$ & 7.41 & 29.63 & 22.22 & 14.81 & 7.41 & 14.81 & 7.41 & 11.11 & 7.41 & 14.81 & 7.41 \\
\hline$N$ & 3.70 & 18.52 & 14.81 & 3.70 & 7.41 & 7.41 & 0.00 & 7.41 & 7.41 & 25.93 & 3.70 \\
\hline LF & 14.81 & 11.11 & 7.41 & 25.93 & 7.41 & 11.11 & 22.22 & 44.44 & 25.93 & 37.04 & 18.52 \\
\hline NL & 74.07 & 40.74 & 55.56 & 55.56 & 77.78 & 66.67 & 70.37 & 37.04 & 59.26 & 22.22 & 70.37 \\
\hline LE & 11.11 & 48.15 & 37.04 & 18.52 & 14.81 & 22.22 & 7.41 & 18.52 & 14.81 & 40.74 & 11.11 \\
\hline
\end{tabular}

PRA: potential response to fertilization; P: positive, with high probability; Pz: positive, with low probability; Z: null; Nz: negative, with low probability; N: negative, with high probability; LF: limit for missing; NL: non-limiting; LE: limit for excess.

all the classes, because the $\chi^{2}$ value calculated was below the $\chi^{2}$ tabulated $(\mathrm{P}=0.05)$, revealing the inefficiency of PRA as an interpretation tool (Table 3 ).

By grouping the responses of the high and low productivity classes for the conditions of lack and excess, $\mathrm{p}+\mathrm{pz}$ and $\mathrm{n}+\mathrm{nz}$; respectively, a frequency of occurrence in terms of lack of nutrients (LF) or higher PRA was obtained; as well as decreasing frequency of excess nutrient limitation (LE) or lower PRA. High productivity population showed the presence of the LF nutrients for atemoya in the order of $\mathrm{Zn}>\mathrm{Mn}>\mathrm{Cu}=$ $\mathrm{Fe}>\mathrm{N}=\mathrm{P}>\mathrm{Ca}=\mathrm{Mg}=\mathrm{S}>\mathrm{B}>\mathrm{K}$; and for $\mathrm{LE}$ the order was as follows: $\mathrm{Zn}=\mathrm{Mn}>\mathrm{Fe}=\mathrm{S}>\mathrm{Cu}=\mathrm{N}=\mathrm{P}=\mathrm{K}>$ $\mathrm{Ca}=\mathrm{Mg}=\mathrm{B}$. In the low productivity population, the order in which the LF nutrients for atemoya appeared was $\mathrm{Cu}>\mathrm{Mn}>\mathrm{Fe}=\mathrm{Ca}>\mathrm{B}>\mathrm{Zn}>\mathrm{N}>\mathrm{P}=\mathrm{S}>\mathrm{Mg}=\mathrm{S}$; whereas for $\mathrm{LE}$ the order was $\mathrm{P}>\mathrm{Mn}>\mathrm{K}>\mathrm{S}>\mathrm{Ca}=$ $\mathrm{Cu}>\mathrm{Mg}=\mathrm{Fe}>\mathrm{N}=\mathrm{Zn}>\mathrm{B}$ (Table 2).

Copper limitation by LF in the low productivity stands was reported in 12 plots (Table 2). The mean $\mathrm{pH}\left(\mathrm{CaCl}_{2}\right)$ was 6.5 ; although, higher values were recorded in the non-limiting plots $(5,8)$. On analysis, the LF plots revealed a leaf $\mathrm{Cu}$ concentration of $31.2 \%$ below the value reported in the non-limiting plots (NL). The soil analysis; however, revealed the opposite behavior, with $120 \%$ higher $\mathrm{Cu}$ concentration. This is due to the high calcium $(\mathrm{Ca})$ and phosphorus
(P) levels of these soils, which lower the degree of their absorption (MAKSYMIEC \& BASZŃSKI, 1998; RANADE-MALVI, 2011). Manganese (Mn) was revealed as the second main limitation in terms of lack in the low productivity areas, recorded in 10 plots. The mean $\mathrm{pH}\left(\mathrm{CaCl}_{2}\right)$ was 6.4 , and values above this, which were recorded in the standsand were not regarded as limiting factors $(6,1)$. In these regions the $\mathrm{P}$ concentrations were considered to be very high (RAIJ et al., 1997), showing an average $255 \mathrm{mg} \mathrm{dm}^{-3}$. $\mathrm{Mn}$ and $\mathrm{P}$ are antagonistic elements (BARBEN et al., 2010). When the $P$ concentration increases it affects the Mn availability to the plant. Mn was considered the second greatest limitation in terms of excess, noted in 11 plots, having a soil $\mathrm{pH}$ value of $5.6\left(\mathrm{CaCl}_{2}\right)$. In this instance, the greater availability of $\mathrm{Mn}$ to the plant was explained by the efficient plant root system going below the $0.20 \mathrm{~m}$ depth, which is the restricted depth for the soil analysis. However, the strongest limitation in terms of excess was caused by $\mathrm{P}$ in 13 plots, with soil concentration of $351.3 \mathrm{mg} \mathrm{dm}^{-3}$ on average. For perennial crops; therefore, (RAIJ et al., 1997), this implied that this average concentration was $485.5 \%$ higher than the base value for the very high class, indicating, excessive P management over time.

The IBNm values recorded for the nutrients in terms of the productivity in all plots 
Table 3 - Frequencies of nutrients as limiting by excess $(\mathrm{LE}=\mathrm{n}+\mathrm{nz})$, equilibrium $(\mathrm{NL}=\mathrm{z})$ and lack $(\mathrm{LF}=\mathrm{p}+\mathrm{pz}), \mathrm{PRA}$ and chi-square $\left(\chi^{2}\right)$. The high and low productivity of the 'Thompson' subpopulations.

\begin{tabular}{|c|c|c|c|c|c|c|c|c|}
\hline & -------------- & h Producti & -------------- & \multirow{3}{*}{$\chi^{2}$} & \multirow{2}{*}{\multicolumn{3}{|c|}{ 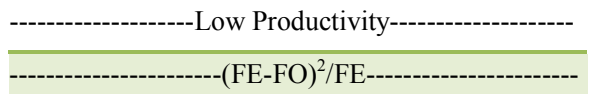 }} & \multirow{3}{*}{$\chi^{2}$} \\
\hline & \multicolumn{3}{|c|}{ 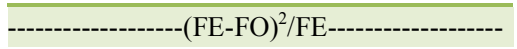 } & & & & & \\
\hline & LE & NL & LF & & LE & NL & LF & \\
\hline $\mathrm{N}$ & 2.28 & 9.52 & 1.35 & $13.15^{* *}$ & 4.73 & 21.68 & 3.45 & $29.87^{* *}$ \\
\hline $\mathrm{P}$ & 2.28 & 9.52 & 1.35 & $13.15^{* *}$ & 1.03 & 1.80 & 4.73 & $7.56^{* *}$ \\
\hline $\mathrm{K}$ & 2.28 & 21.92 & 6.48 & $30.68^{* *}$ & 0.00 & 7.92 & 6.23 & $14.15^{* *}$ \\
\hline $\mathrm{Ca}$ & 3.44 & 15.08 & 2.28 & $20.80^{* *}$ & 2.36 & 7.92 & 0.81 & $11.09^{* *}$ \\
\hline $\mathrm{Mg}$ & 3.44 & 15.08 & 2.28 & $20.80^{* *}$ & 3.45 & 25.25 & 6.23 & $34.93^{* *}$ \\
\hline S & 0.67 & 7.21 & 2.28 & $10.16^{* *}$ & 1.48 & 15.36 & 4.73 & $21.58^{* *}$ \\
\hline B & 3.44 & 21.92 & 4.84 & $30.21^{* *}$ & 6.23 & 18.39 & 1.48 & $26.10^{* *}$ \\
\hline $\mathrm{Cu}$ & 2.28 & 7.21 & 0.67 & $10.16^{* *}$ & 2.36 & 0.94 & 0.48 & $3.79 \mathrm{~ns}$ \\
\hline $\mathrm{Fe}$ & 0.67 & 3.56 & 0.67 & $4.90 \mathrm{~ns}$ & 3.45 & 10.13 & 0.81 & $14.39^{* *}$ \\
\hline $\mathrm{Mn}$ & 0.22 & 1.19 & 0.22 & $1.63 \mathrm{~ns}$ & 0.14 & 0.25 & 0.00 & $0.40 \mathrm{~ns}$ \\
\hline $\mathrm{Zn}$ & 0.02 & 0.01 & 0.05 & $0.08 \mathrm{~ns}$ & 4.73 & 18.39 & 2.36 & $25.49^{* *}$ \\
\hline$\chi^{2}$ & $21.00^{*}$ & $112.25^{* *}$ & $22.47^{*}$ & $155.71^{* *}$ & $29.98^{* *}$ & $128.04^{* *}$ & $31.32^{* *}$ & $189.34^{* *}$ \\
\hline
\end{tabular}

$\chi^{2}$ Tabulated at 5\%: 18,3 and 31,4 for 10 (nutrients) and 20 (gross of observations) degrees of freedom; ns, ${ }^{*},{ }^{* *}:$ not significant, significant at 1 and $5 \%$ probability, respectively.

was obvious as a linear equation with a practically null Pearson correlation coefficient, in which $\mathrm{r}=0.04$ $\left(\mathrm{R}^{2}=0.0016\right)$. From the regression model it is evident that IBNm does not reveal data to indicate whether the fruit yield has any important association with the nutrient balance index estimated by the DRIS method. However, the DRIS indices for the nutrients $\mathrm{P}, \mathrm{Ca}, \mathrm{Mg}, \mathrm{S}, \mathrm{Cu}, \mathrm{Fe}, \mathrm{Mn}$ and $\mathrm{Zn}$ (Table 4) presented mathematical models with determination coefficients equal to or higher than $80 \%\left(\mathrm{R}^{2} \geq 0.80\right)$.
Critical values are calculated by equating the indices of each equation to zero as shown in table 4. Results of linear and logarithmic models, and the second order polynomials, by the first root of the Bhaskara formula $\left(x^{\prime}=\left(-b+\left(b^{2}-4 a c\right)^{1 / 2}\right) / 2 a\right)$ were added and subtracted from the value of $2 / 3$ of standard deviations of the nutrient concentrations of each sample, enabling the establishment of the normal distribution ranges for the nutrients, thus facilitating a comparison of these ranges with the findings of other authors (Table 5).

Table 4 - Statistical models for determination of the critical nutrient levels among the DRIS indices of the 'Thompson' leaf samples.

\begin{tabular}{llll}
\hline Nutrient & Equations $^{(1)}$ & $\mathrm{R}^{2}$ & Critical level $^{(2)}$ \\
\hline $\mathrm{N}$ & $\mathrm{IN}=0.0761(\mathrm{~N})-2.4302^{* *}$ & 0.37 & $31.9 \mathrm{~g} \mathrm{~kg}^{-1}$ \\
$\mathrm{P}$ & $\mathrm{IP}=-0.255(\mathrm{P})^{2}+1.9592(\mathrm{P})-2.2697^{* *}$ & 0.91 & $1.4 \mathrm{~g} \mathrm{~kg}^{-1}$ \\
$\mathrm{~K}$ & $\mathrm{IK}=0.1678(\mathrm{~K})-2.6564^{* *}$ & 0.43 & $15.8 \mathrm{~g} \mathrm{~kg}^{-1}$ \\
$\mathrm{Ca}$ & $\mathrm{ICa}=-0.005(\mathrm{Ca})^{2}+0.3024(\mathrm{Ca})-3.3159^{* *}$ & 0.81 & $14.4 \mathrm{~g} \mathrm{~kg}^{-1}$ \\
$\mathrm{Mg}$ & $\mathrm{IMg}=-0.0474(\mathrm{Mg})^{2}+0.8864(\mathrm{Mg})-2.291^{* *}$ & 0.83 & $3.1 \mathrm{~g} \mathrm{~kg}^{-1}$ \\
$\mathrm{~S}$ & $\mathrm{IS}=0.901(\mathrm{~S})-1.739^{* *}$ & 0.79 & $1.9 \mathrm{~g} \mathrm{~kg}^{-1}$ \\
$\mathrm{~B}$ & $\mathrm{IB}=-4.10^{-4}(\mathrm{~B})^{2}+0.0825(\mathrm{~B})-3.6822^{* *}$ & 0.62 & $65.3 \mathrm{mg} \mathrm{kg}^{-1}$ \\
$\mathrm{Cu}$ & $\mathrm{ICu}=-4.5 .10^{-3}(\mathrm{Cu})^{2}+0.284(\mathrm{Cu})-2.4225^{* *}$ & 0.91 & $10.2 \mathrm{mg} \mathrm{kg}^{-1}$ \\
$\mathrm{Fe}$ & $\mathrm{IFe}=-8.10^{-5}(\mathrm{Fe})^{2}+0.0386(\mathrm{Fe})-2.8798^{* *}$ & 0.86 & $92.2 \mathrm{mg} \mathrm{kg}^{-1}$ \\
$\mathrm{Mn}$ & $\mathrm{IMn}=-7.10^{-5}(\mathrm{Mn})^{2}+0.0308(\mathrm{Mn})-2.124^{* *}$ & 0.95 & $85.6 \mathrm{mg} \mathrm{kg}^{-1}$ \\
$\mathrm{Zn}$ & $\mathrm{IZn}=-2.10^{-4}(\mathrm{Zn})^{2}+0.0501(\mathrm{Zn})-1.5242^{* *}$ & 0.94 & $35.4 \mathrm{mg} \mathrm{kg}^{-1}$ \\
\hline
\end{tabular}

${ }^{* *}$ Significant at $1 \%$ for the Kolmogorov-Smirnov constant variance test; ${ }^{(1)}$ Statistical model of regression analysis. Relating nutrient contents to their respective indices; ${ }^{(2)}$ Critical level (NC) values. or sufficient content. obtained by assigning null value to the indices of the equations of each nutrient. 
Table 5 - Normal ranges (adequate levels) of nutrients in the 'Thompson' atemoieiras leaf samples in relation to the findings of other authors for the same species. and other Annonaceae.

\begin{tabular}{|c|c|c|c|c|c|c|}
\hline \multirow{2}{*}{ References } & $\mathrm{N}$ & $\mathrm{P}$ & $\mathrm{K}$ & $\mathrm{Ca}$ & $\mathrm{Mg}$ & $\mathrm{S}$ \\
\hline & \multicolumn{6}{|c|}{ 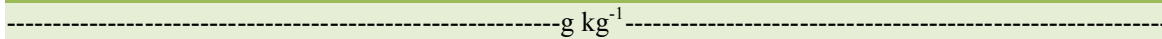 } \\
\hline DRIS - Atemoia ${ }^{\mathrm{I}}$ & 29.8-34.7 & $0.9-1.9$ & $14.0-17.0$ & $11.0-17.8$ & $2.2-4.0$ & $1.5-2.4$ \\
\hline George et al. $(2002)^{I I}$ & $24.0-32.0$ & $1.5-2.1$ & $10.0-15.0$ & $10.0-16.0$ & $3.5-4.0$ & - \\
\hline Sanewski (1991) ${ }^{\mathrm{II}}$ & $25.0-30.0$ & $1.6-2.0$ & $10.0-15.0$ & $6.0-10.0$ & $3.5-5.0$ & - \\
\hline Anonymous $(1995)^{\mathrm{IVa}}$ & $27.5-32.5$ & $1.5-2.0$ & $13.0-18.0$ & $4.0-9.0$ & $3.0-5.0$ & - \\
\hline Anonymous $(1995)^{\mathrm{IVb}}$ & $26.0-31.0$ & $1.1-1.5$ & $8.0-12.0$ & $4.0-15.0$ & $3.0-5.0$ & - \\
\hline \multirow[t]{3}{*}{ Andrade $(2004)^{\mathrm{V}}$} & $25.0-28.0$ & $1.4-9.0$ & $18.0-26.0$ & $12.0-18.0$ & $2.0-4.0$ & $1.6-2.0$ \\
\hline & B & $\mathrm{Cu}$ & $\mathrm{Fe}$ & $\mathrm{Mn}$ & \multicolumn{2}{|c|}{$\mathrm{Zn}$} \\
\hline & \multicolumn{6}{|c|}{ 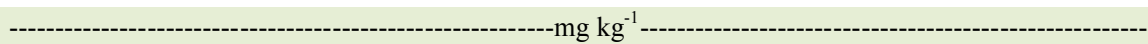 } \\
\hline DRIS - Atemoia ${ }^{\mathrm{I}}$ & $57-73$ & 6-14 & $69-113$ & $42-127$ & \multicolumn{2}{|c|}{$18-50$} \\
\hline George et al. $(2002)^{I I}$ & $18-30$ & $10-20$ & $50-110$ & $60-140$ & \multicolumn{2}{|c|}{$40-70$} \\
\hline Sanewski $(1991)^{\mathrm{II}}$ & $15-40$ & $10-20$ & $50-70$ & $30-90$ & \multicolumn{2}{|c|}{$15-30$} \\
\hline Anonymous (1995) $)^{\mathrm{III}}$ & $30-50$ & $5-40$ & $40-80$ & $200-350$ & \multicolumn{2}{|c|}{$8-20$} \\
\hline
\end{tabular}

${ }^{\mathrm{I}}$ Normal ranges obtained by equations equal to zero $\pm{ }^{2} / 3$ of the standard deviation of the contents of each nutrient; ${ }^{\mathrm{II}}$ Atemoya (Annona cherimola Mill. Annona squamosa L); ${ }^{\mathrm{II}}$ Cherimoya (Annona cherimola Mill.); ${ }^{\mathrm{IV}}$ Fruit-Pineapple (Annona squamosa L.): a) May-June. b) September-December; ' Graviola (Annona muricata).

Levels identified by the DRIS standard (Table 5) revealed close similarities to those reported for the atemoya culture by GEORGE et al. (2002) and SANEWSKI (1991). ANONYMOUS (1995) in their study on Custard apple at two different sampling times reported findings close to those assessed by the DRIS standard for atemoya. One factor that could have facilitated this occurrence is that these are the parental species of the hybrid atemoya. In the case of the micronutrients, the normal bands identified were quite divergent, barring copper, from the results recorded in the literature. This difference is possibly because the studies done by GEORGE et al. (2002), SANEWSKI (1991) and ANONYMOUS (1995) were performed in locations with very distinct environmental conditions. GEORGE et al. (2002) and SANEWSKI (1991) had performed their study in Brisbane, the capital of Queensland, Australia, where a subtropical climate prevails with its characteristic hot summers, (Cfa) according to Köppen-Geiger.

\section{CONCLUSION}

For the high and low productivity populations, the order of limitation by lack or excess are quite divergent, with the order of limitation by lack in the population of low productivity being as follows: $\mathrm{Zn}>\mathrm{Mn}>\mathrm{Cu}=\mathrm{Fe}>\mathrm{N}=\mathrm{P}>\mathrm{Ca}=\mathrm{Mg}=\mathrm{S}>$ $\mathrm{B}>\mathrm{K}$; the order of limitation by excess in the high productivity population was given as follows: $\mathrm{P}>$ $\mathrm{Mn}>\mathrm{K}>\mathrm{S}>\mathrm{Ca}=\mathrm{Cu}>\mathrm{Mg}=\mathrm{Fe}>\mathrm{N}=\mathrm{Zn}>\mathrm{B}$.
The relationships between the mean nutrient balance index and the productivity in the stands (high and low yields) were inadequate to clearly estimate the manner in which fruit production was connected with the nutritional state of the plants; the potential of the response to fertilization was reported to be an inefficient method.

The DRIS indices of the nutrients, isolated for $\mathrm{P}, \mathrm{Ca}, \mathrm{Mg}, \mathrm{S}, \mathrm{Cu}, \mathrm{Fe}, \mathrm{Mn}$ and $\mathrm{Zn}$, were adequate to establish the deficiency, excess or balance of these nutrients.

\section{REFERENCES}

ANDRADE, L.R.M. de. Corretivos e fertilizantes para culturas perenes e semiperenes. In: SOUSA, D.M.G. de; LOBATO, E. (Eds.). Cerrado: correção do solo e adubação. Brasília: Embrapa Informação Tecnológica, 2004. p.317-366.

ANONYMOUS. Production and marketing of sweetsop. Taiwan: Taitung District Agricultural Improvement Station, 1995. N.1. 48p. (In Chinese).

BATAGLIA, O.C. et al. Método de análises química de plantas. Campinas: Instituto Agronômico, 1983. 48p.

BARBEN, S.A. et al. Phosphorus and manganese interactions and their relationships with zinc in chelator-bufered solution grown russet Burbank potato. Journal of Plant Nutrition, v.33, p.752-769, 2010. Available from: <http://dx.doi. org/10.1080/01904160903575964>. Accessed: Oct. 30, 2016. doi: $10.1080 / 01904160903575964$.

BEAUFILS, E.R. Diagnosis and recommendation integrated system (DRIS): a general scheme for experimentation and 
calibration based on principles develop from research in plant nutrition. Pietermaritzburg: University of Natal, 1973. 132p. (Soil Science Bulletin, 1).

BEVERLY, R.B. Comparison of DRIS and alternative nutrient diagnostic methods for soybean. Journal of Plant Nutrition, v.10, p.901-920, 1987. Available from: <http://dx.doi. org/10.1080/01904168709363619>. Accessed: Oct. 30, 2015. doi: $10.1080 / 01904168709363619$.

GEORGE, A.P. et al. New leaf nutrient standards for atemoya (Annona spp. hybrids). Journal of Agricultural Science, v.35, n.1, p.41-50, 2002. Available from: <http://kukr.lib.ku.ac.th/db/BKN AGRI/search_detail/result/98544>. Accessed: Mar. 15, 2016.

GUIMARÃES, P.R.B. Métodos quantitativos estatísticos. Curitiba: IESDE Brasil, 2008. 254p.

MAKSYMIEC, W.; BASZYŃSKI, T. The role of $\mathrm{Ca}$ ions in changes induced by excess $\mathrm{Cu}^{2+}$ in bean plants. Growth parameters. Acta Physiologiae Plantarum, v.20, p.411-417, 1998. Available from: <http://dx.doi.org/10.1007/s11738-998-0028-y>. Accessed: Oct. 30, 2016. doi: 10.1007/s11738-998-0028-y.

RAIJ, B. van et al. Recomendações de adubação e calagem para o Estado de São Paulo. 2.ed. Campinas: Instituto Agronômico \& Fundação IAC, 1997. 285p. (Boletim Técnico, 100).

RANADE-MALVI, U. Interaction of micronutrients with major nutrients with special reference to potassium. Journal of Agricultural Sciences, v.24, p.106-109, 2011. Available from: $\quad<$ http://www.inflibnet.ac.in/ojs/index.php/KJAS/article/ viewFile/865/795>. Accessed: Oct. 27, 2016.

ROZANE, D.E.; NATALE, W. Liming, fertilizer and mineral nutrition of Annonaceae. Revista Brasileira de Fruticultura, v.36, p.166-175, 2014. Available from: <http://dx.doi.org/10.1590/ S0100-29452014000500020>. Accessed: Oct. 29, 2016. doi: 10.1590/S0100-29452014000500020.

SANEWSKI, G.M. Custard apples: cultivation and crop protection. Brisbane: Queensland Department of Primary Industry, 1991. 103p.

SILVA, A.V.C. da; MUNIZ, E.N. Qualidade de atemoia colhida em dois estádios de maturação. Revista Caatinga, v.24, p.9-13, 2011. Available from: <http://periodicos.ufersa.edu.br/revistas/index. php/sistema/article/view/1875/pdf >. Accessed: Nov. 01, 2015.

SILVA, G.G.C. da et al. Evaluation of the universality of DRIS, M-DRIS, and CND norms. Revista Brasileira de Ciência do Solo, v.29, p.755-761, 2005. Available from: <http://dx.doi.org/10.1590/ S0100-06832005000500011>. Accessed: Oct. 24, 2015. doi: 10.1590/S0100-06832005000500011.

SOUZA, H.A. et al. Assessment of nutritional status of guava seedlings using preliminary DRIS norms and sufficiency ranges. Journal of Plant Nutrition, v.38, p.1611-1618, 2015. Available from: <http://dx.doi.org/10.1080/01904167.2015.1017050>. Accessed: Oct. 29, 2015. doi: 10.1080/01904167.2015.1017050.

URANO, E.M.O. et al. Soybean nutritional status evaluation. Pesquisa Agropecuária Brasileira, v.41, p.1421-1428, 2006. Available from: <http://dx.doi.org/10.1590/S0100204X2006000900011>. Accessed: Oct. 22, 2015. doi: 10.1590/ S0100-204X2006000900011.

WADT, P.G.S. Relationships between soil class and nutritional status of coffee plantations. Revista Brasileira de Ciência do Solo, v.29, p.227-234, 2005. Available from: <http://dx.doi. org/10.1590/S0100-06832005000200008>. Accessed: Oct. 28, 2015. doi: 10.1590/S0100-06832005000200008. 